\title{
Emerging concepts for PI3K/mTOR inhibition as a potential
}

\section{treatment for osteosarcoma [version 1; peer review: 2}

\section{approved]}

\author{
Michael W. Bishop ${ }^{1,2}$, Katherine A. Janeway ${ }^{3}$ \\ ${ }^{1}$ Department of Oncology, St Jude Children's Research Hospital, Memphis, TN, USA \\ ${ }^{2}$ Department of Pediatrics, University of Tennessee Health Science Center, Memphis, TN, USA \\ ${ }^{3}$ Boston Children's Cancer and Blood Disorders Center, Boston, MA, USA
}

V1 First published: 06 Jul 2016, 5(F1000 Faculty Rev):1590
https://doi.org/10.12688/f1000research.8228.1

Latest published: 06 Jul 2016, 5(F1000 Faculty Rev):1590

https://doi.org/10.12688/f1000research.8228.1

\begin{abstract}
Patients with metastatic and recurrent osteosarcoma fare poorly, and new therapeutic strategies are needed to improve survival. Several recent complementary genomic and pathway analyses of both murine and human osteosarcoma have revealed common aberrations of the phosphoinositide 3-kinase (PI3K)/mammalian target of rapamycin (mTOR) pathway in osteosarcoma. Preclinical data demonstrate that inhibition of PI3K and mTOR with either a combination of single agents or dual inhibiting compounds can decrease cell proliferation and induce cell cycle arrest and apoptosis. With a lack of available clinical agents active in osteosarcoma, PI3K/mTOR inhibition represents a potential vulnerability in osteosarcoma that warrants clinical investigation.

Keywords

osteosarcoma , PI3K, mTOR , inhibition treatment
\end{abstract}

\section{Open Peer Review \\ Approval Status \\ 1 \\ 2 \\ version 1 \\ 06 Jul 2016 \\ Faculty Reviews are review articles written by the prestigious Members of Faculty Opinions. The articles are commissioned and peer reviewed before publication to ensure that the final, published version is comprehensive and accessible. The reviewers who approved the final version are listed with their names and affiliations.}

1. Erik H Danen, Leiden University, Leiden, The Netherlands

2. Giovanni Grignani, Candiolo Cancer Institute FPO, IRCCS, Candiolo, Italy University of Torino Medical School, Candiolo, Italy

Lorenzo D'Ambrosio, Candiolo Cancer Institute FPO, IRCCS, Candiolo, Italy University of Torino Medical School, Candiolo, Italy 
Any comments on the article can be found at the end of the article.

Corresponding author: Katherine A. Janeway (katherine_janeway@dfci.harvard.edu)

Competing interests: The authors have no conflicts of interest to disclose.

Grant information: The author(s) declared that no grants were involved in supporting this work.

Copyright: @ 2016 Bishop MW and Janeway KA. This is an open access article distributed under the terms of the Creative Commons Attribution License, which permits unrestricted use, distribution, and reproduction in any medium, provided the original work is properly cited.

How to cite this article: Bishop MW and Janeway KA. Emerging concepts for PI3K/mTOR inhibition as a potential treatment for osteosarcoma [version 1; peer review: 2 approved] F1000Research 2016, 5(F1000 Faculty Rev):1590

https://doi.org/10.12688/f1000research.8228.1

First published: 06 Jul 2016, 5(F1000 Faculty Rev):1590 https://doi.org/10.12688/f1000research.8228.1 


\section{Introduction}

Osteosarcoma is the most common malignancy of bone diagnosed in children and adolescents, with an age-adjusted incidence of 4.4 new cases per million each year ${ }^{1}$. Contemporary studies estimate that with the use of surgery and multimodal chemotherapy with high-dose methotrexate, cisplatin, and doxorubicin, 65 to $70 \%$ of patients are able to achieve long-term cure ${ }^{2}$. However, patients who present with metastatic disease fare poorly, with survival rates less than $30 \%^{3-5}$. Furthermore, for patients who relapse, survival is less than $20 \%$, and cure is nearly impossible if surgical complete remission cannot be achieved ${ }^{6,7}$. Several avenues for augmenting treatment are currently under preclinical or clinical investigations, supported by recent biologic and genomic data. Among these, interest has been raised for the use of drugs targeting the phosphoinositide 3-kinase (PI3K)/mammalian target of rapamycin (mTOR) pathway as a potential vulnerability. Aberrations of this pathway have previously been described in osteosarcoma, such as PTEN deletion ${ }^{8}$ and $P I K 3 C A$ mutations ${ }^{9}$, but were observed at relatively low frequency. However, contemporary biologic studies now reveal more frequent alterations of this pathway. The following brief review will highlight recent analyses supporting the role of $\mathrm{PI} 3 \mathrm{~K} / \mathrm{mTOR}$ inhibition as an area ripe for further exploration in osteosarcoma.

\section{Genetic studies reveal potential role for PI3Km/TOR inhibition in osteosarcoma}

As part of efforts to identify targets for novel therapeutic agents, institutional and collaborative group efforts to characterize the genomic landscape of osteosarcoma have been conducted with the hope of identifying targetable recurrent aberrations. Numerous genomic and epigenetic analyses have revealed the striking genomic complexity and heterogeneity among osteosarcoma samples but have also elucidated a few common themes including alterations of TP53 and/or RB1 in most samples, and distinct chromosomal regions of hypermutation ("kataegis") $)^{10,11}$. However, a recent complementary genomic and pathway analysis identified $\mathrm{PI} 3 \mathrm{~K} / \mathrm{mTOR}$ pathway aberrations in a subset of osteosarcoma samples. Heuristic analysis of whole genome, exome, and RNA sequencing data from 59 osteosarcoma tumors revealed alterations in the PI3K/mTOR pathway in $24 \%$ of samples that included aberrations of PTEN, TSC2, PIK3R1, PIK3CA, and several other genes. Using a comparative oncology approach, whole exome sequencing of a $T p 53 / R b 1$ conditionally deleted osteosarcoma mouse model, somatic mutations in PTEN and PIK3RI were observed in both murine and human tumors. Furthermore, a genome-wide shRNA screen of a primary murine osteosarcoma cell line identified 172 enriched genes including Pik3ca and Mtor, with inhibition of murine osteosarcoma cells ${ }^{11}$. Based on this information, two dual PI3K/mTOR inhibitors (GSK2126458, BEZ-235) and a PIK3CA-specific inhibitor (PIK75) were tested against human and murine-derived cell lines. All three drugs inhibited cell proliferation in all cell lines; PIK75 and GSK2126458 induced apoptosis as demonstrated by caspase $3 / 7$ activation and poly(ADP-ribose) polymerase (PARP) cleavage.

In a separate systematic analysis, whole-genome siRNA screening of primary osteosarcoma cell cultures derived from a genetically engineered murine model revealed enrichment in pathways associated with protein translation and mTOR signaling. A small molecule/kinase inhibitor screen of murine-derived osteosarcoma cell lines revealed activity in compounds (PIK-75, GSK2126458, and BEZ-235) targeting PI3K and mTOR and/or DNA-PK. Activity of dual PI3K/mTOR inhibitors was subsequently observed in cell death assays of cultures from primary human xenograftderived osteosarcoma (GSK2126458, PKI-587, BEZ-235, and BGT-226). Administration of the compounds GSK2126458 and PKI-587 inhibited phosphorylation of downstream targets in a dose-dependent manner, increased the number of cells in the $\mathrm{G}_{0}-\mathrm{G}_{1}$ phase, and induced apoptosis in both murine and human cell lines. Combinations of PI3K- or mTOR-specific inhibitors were also evaluated, and while individual activity was not observed, combination of the PIK3CA-specific inhibitor BYL719 and everolimus yielded a synergistic interaction ${ }^{12}$.

Further supporting these comprehensive analyses, the use of novel genetic screening technologies provides additional evidence for the importance of the PI3K/mTOR pathway in osteosarcoma. A Sleeping Beauty (SB) transposon-based forward genetic screen was performed in mice with and without somatic loss of Trp53 to identify common insertion sites associated with the development of osteosarcoma. Pten was one of the most commonly mutated genes in both Trp53-SB-mutated and non-Trp53-SB-mutated tumors. $N f 2$ and $N f 1$, both of which serve regulatory functions for downstream mTOR signaling, were also frequently mutated in the SB-mutated tumors. Pathway analysis identified enrichment for candidate genes in the PI3K/AKT/mTOR pathway, as well as overlap with the ErbB and ERK/MAPK pathways. Furthermore, conditional knockdown of both Trp53 and Pten in a mouse model accelerated the development of osteosarcoma, and knockout of PTEN in an immortalized osteoblast cell line with inhibited TP53 function led to significantly increased colony formation, suggesting that PTEN loss is cooperative with TP53 dysfunction to drive osteosarcomagenesis and proliferation ${ }^{13}$.

Several clinical reports describing activity of agents targeting mTORC1/2 have included patients with osteosarcoma. A recent report from the French Sarcoma Group of off-label use of targeted therapies for osteosarcoma found that those who received rapamycin (with or without cyclophosphamide) compared to a group of tyrosine kinase inhibitors (sunitinib, sorafenib, and pazopanib) had a superior progression-free survival (PFS) (hazard ratio [HR] 2.7, 95\% confidence interval [CI] 1.05-7.1), although the difference in median PFS was modest (3 months vs. 1.8 months) $)^{14}$. A phase II study of the mTOR inhibitor ridaforolimus included two osteosarcoma patients with a confirmed partial response and one patient with an unconfirmed partial response ${ }^{15}$. Fifty osteosarcoma patients were enrolled on a subsequent phase III study using ridaforolimus as a maintenance therapy but were included in a cohort of bone tumors and were not analyzed separately. In a subgroup analysis, the use of ridaforolimus trended toward improved PFS for bone tumors but did not achieve statistical significance (HR 0.70, 95\% CI upper limit $>1$ ); the study was not powered for subgroup analyses ${ }^{16}$.

Everolimus has also demonstrated some activity in osteosarcoma; in a pediatric phase I study, one of two enrolled osteosarcoma patients experienced prolonged stable disease for eight courses ${ }^{17}$. Everolimus has been shown to decrease drug-induced resistance 
to sorafenib via abrogation of the upregulation of mTORC1 and mTORC2 in murine models ${ }^{18}$; the combination of sorafenib and everolimus in an adult phase II study in patients with recurrent osteosarcoma with measurable disease yielded a 6-month PFS of $45 \%{ }^{19}$. These results are in stark contrast to those observed in an historical cohort of osteosarcoma patients enrolled in phase II trials (Lagmay $\mathrm{J}$ et al., J Clin Oncol, in press). A recently completed phase I study of everolimus in combination with pazopanib for the treatment of adults with advanced solid tumors demonstrated tolerability; prolonged stable disease or partial response was observed for several patients with PI3K/AKT/mTOR pathway alterations ${ }^{20}$. Not all published studies have supported activity of mTOR inhibition in osteosarcoma; prior combinations of rapamycin with cyclophosphamide and temsirolimus with the insulin-like growth factor-1 receptor (IGF-1R) antibody cixutumumab failed to demonstrate efficacy in phase II studies including recurrent osteosarcoma patients ${ }^{21-23}$. However, when viewed as a whole, the available clinical data suggest potential activity of inhibition of the PI3K/mTOR pathway in osteosarcoma, which warrants further investigation.

\section{Conclusions}

The above data present compelling evidence of the role for dysregulation of the PI3K/mTOR pathway in osteosarcoma and suggest an opportunity for focused therapeutic strategies. Prior studies of mTOR inhibitors in osteosarcoma have demonstrated a hint of activity for targeting this pathway but were not adequate to assess the activity of PI3K/mTOR inhibition in osteosarcoma due to study design, lack of molecular correlation, and/or the number of patients enrolled. Furthermore, evidence that combinations of PI3K and mTOR inhibition can overcome patterns of resistance observed in single agent exposures and combination therapy shows potential promise for clinical activity. Given the paucity of active agents available for the treatment of recurrent and refractory osteosarcoma, inhibition of PI3K and mTOR may present a viable treatment strategy deserving of clinical investigation. It remains unclear whether the presence of aberrations within the pathway truly function as biomarkers of susceptibility to targeted agents; therefore, as a component of any future prospective studies of PI3K/mTOR inhibition, genomic analysis and assessment of activity of the pathway should be included as correlative biology studies.

\section{Competing interests}

The authors have no conflicts of interest to disclose.

\section{Grant information}

The author(s) declared that no grants were involved in supporting this work.
1. Mirabello L, Troisi RJ, Savage SA: Osteosarcoma incidence and survival rates from 1973 to 2004: data from the Surveillance, Epidemiology, and End Results Program. Cancer. 2009; 115(7): 1531-43. PubMed Abstract | Publisher Full Text | Free Full Text

2. Meyers PA, Schwartz CL, Krailo M, et al:: Osteosarcoma: a randomized, prospective trial of the addition of ifosfamide and/or muramyl tripeptide to cisplatin, doxorubicin, and high-dose methotrexate. J Clin Oncol. 2005; 23(9): 2004-11.

PubMed Abstract | Publisher Full Text

3. Kager L, Zoubek A, Pötschger U, et al.: Primary metastatic osteosarcoma: presentation and outcome of patients treated on neoadjuvant Cooperative Osteosarcoma Study Group protocols. J Clin Oncol. 2003; 21(10): 2011-8. PubMed Abstract | Publisher Full Text

4. Ebb $\mathrm{D}$, Meyers $\mathrm{P}$, Grier $\mathrm{H}$, et al: Phase II trial of trastuzumab in combination with cytotoxic chemotherapy for treatment of metastatic osteosarcoma with human epidermal growth factor receptor 2 overexpression: a report from the children's oncology group. J Clin Oncol. 2012; 30(20): 2545-51. PubMed Abstract | Publisher Full Text | Free Full Text

5. Briccoli A, Rocca M, Salone M, et al.: High grade osteosarcoma of the extremities metastatic to the lung: long-term results in 323 patients treated combining surgery and chemotherapy, 1985-2005. Surg Oncol. 2010; 19(4): 193-9. PubMed Abstract | Publisher Full Text

6. Kempf-Bielack B, Bielack SS, Jürgens $\mathrm{H}$, et al:: Osteosarcoma relapse after combined modality therapy: an analysis of unselected patients in the Cooperative Osteosarcoma Study Group (COSS). J Clin Oncol. 2005; 23(3): $559-68$.

PubMed Abstract | Publisher Full Text

7. F Bielack SS, Kempf-Bielack B, Branscheid D, et al.: Second and subsequent recurrences of osteosarcoma: presentation, treatment, and outcomes of 249 consecutive cooperative osteosarcoma study group patients. J Clin Oncol. 2009; 27(4): 557-65.

PubMed Abstract | Publisher Full Text | F1000 Recommendation

8. Freeman SS, Allen SW, Ganti R, et al.: Copy number gains in EGFR and copy number losses in PTEN are common events in osteosarcoma tumors. Cancer. 2008; 113(6): 1453-61.

PubMed Abstract | Publisher Full Text | Free Full Text

9. Choy E, Hornicek F, MacConaill L, et al:: High-throughput genotyping in osteosarcoma identifies multiple mutations in phosphoinositide-3-kinase and other oncogenes. Cancer. 2012; 118(11): 2905-14.

PubMed Abstract | Publisher Full Text | Free Full Text

10. $\mathrm{F}$ Chen $\mathrm{X}$, Bahrami A, Pappo A, et al.: Recurrent somatic structural variations contribute to tumorigenesis in pediatric osteosarcoma. Cell Rep. 2014; 7(1): 104-12.

PubMed Abstract | Publisher Full Text | Free Full Text | F1000 Recommendation

11. Perry JA, Kiezun A, Tonzi $P$, et al.: Complementary genomic approaches highlight the $\mathrm{PI} 3 \mathrm{~K} / \mathrm{mTOR}$ pathway as a common vulnerability in osteosarcoma. Proc Natl Acad Sci U S A. 2014; 111(51): E5564-73.

PubMed Abstract | Publisher Full Text | Free Full Text

12. F Gupte A, Baker EK, Wan SS, et al:: Systematic Screening Identifies Dua PI3K and mTOR Inhibition as a Conserved Therapeutic Vulnerability in Osteosarcoma. Clin Cancer Res. 2015; 21(14): 3216-29.

PubMed Abstract | Publisher Full Text | Free Full Text | F1000 Recommendation

13. F Moriarity BS, Otto GM, Rahrmann EP, et al:: A Sleeping Beauty forward genetic screen identifies new genes and pathways driving osteosarcoma development and metastasis. Nat Genet. 2015; 47(6): 615-24. PubMed Abstract | Publisher Full Text | Free Full Text | F1000 Recommendation

14. F Penel-Page M, Ray-Coquard I, Larcade J, et al:: Off-label use of targeted therapies in osteosarcomas: data from the French registry OUTC'S (Observatoire de I'Utilisation des Thérapies Ciblées dans les Sarcomes). BMC Cancer. 2015; 15: 854 .

PubMed Abstract | Publisher Full Text | Free Full Text | F1000 Recommendation

15. Chawla SP, Staddon AP, Baker LH, et al:: Phase II study of the mammalian target of rapamycin inhibitor ridaforolimus in patients with advanced bone and soft tissue sarcomas. J Clin Oncol. 2012; 30(1): 78-84

PubMed Abstract | Publisher Full Text

16. F Demetri GD, Chawla SP, Ray-Coquard I, et al.: Results of an internationa randomized phase III trial of the mammalian target of rapamycin inhibitor ridaforolimus versus placebo to control metastatic sarcomas in patients after benefit from prior chemotherapy. J Clin Oncol. 2013; 31(19): 2485-92. PubMed Abstract | Publisher Full Text | F1000 Recommendation

17. Fouladi M, Laningham F, Wu J, et al.: Phase I study of everolimus in pediatric patients with refractory solid tumors. J Clin Oncol. 2007; 25(30): 4806-12. PubMed Abstract | Publisher Full Text

18. Pignochino Y, Dell'Aglio C, Basirico M, et al.: The Combination of Sorafenib and 
Everolimus Abrogates mTORC1 and mTORC2 upregulation in osteosarcoma preclinical models. Clin Cancer Res. 2013; 19(8): 2117-31. PubMed Abstract | Publisher Full Text

19. F Grignani G, Palmerini E, Ferraresi V, et al.: Sorafenib and everolimus for patients with unresectable high-grade osteosarcoma progressing after standard treatment: a non-randomised phase 2 clinical trial. Lancet Oncol. 2015; 16(1): 98-107.

PubMed Abstract | Publisher Full Text | F1000 Recommendation

20. F Rodrigues HV, Ke D, Lim J, et al.: Phase I combination of pazopanib and everolimus in PIK3CA mutation positive/PTEN loss patients with advanced solid tumors refractory to standard therapy. Invest New Drugs. 2015; 33(3): 700-9.

PubMed Abstract | Publisher Full Text | F1000 Recommendation
21. F Schwartz GK, Tap WD, Qin LX, et al:: Cixutumumab and temsirolimus for patients with bone and soft-tissue sarcoma: a multicentre, open-label, phase 2 trial. Lancet Oncol. 2013; 14(4): 371-82.

PubMed Abstract | Publisher Full Text | Free Full Text | F1000 Recommendation

22. Wagner LM, Fouladi M, Ahmed A, et al.: Phase II study of cixutumumab in combination with temsirolimus in pediatric patients and young adults with recurrent or refractory sarcoma: a report from the Children's Oncology Group. Pediatr Blood Cancer. 2015; 62(3): 440-4.

Pediatr Blood Cancer. 2015; 62(3): 440-4.
PubMed Abstract | Publisher Full Text | Free Full Text

23. Schuetze SM, Zhao L, Chugh R, et al.: Results of a phase II study of sirolimus and cyclophosphamide in patients with advanced sarcoma. Eur J Cancer. 2012; 48(9): 1347-53.

48(9): 1347-53.
PubMed Abstract | Publisher Full Text 


\section{Open Peer Review}

\section{Current Peer Review Status:}

\section{Editorial Note on the Review Process}

Faculty Reviews are review articles written by the prestigious Members of Faculty Opinions. The articles are commissioned and peer reviewed before publication to ensure that the final, published version is comprehensive and accessible. The reviewers who approved the final version are listed with their names and affiliations.

\section{The reviewers who approved this article are:}

\section{Version 1}

\section{Giovanni Grignani}

${ }_{1}^{1}$ Division of Medical Oncology, Candiolo Cancer Institute FPO, IRCCS, Candiolo, Italy

2 Department of Oncology, University of Torino Medical School, Candiolo, Italy

\section{Lorenzo D'Ambrosio}

1 Division of Medical Oncology, Candiolo Cancer Institute FPO, IRCCS, Candiolo, Italy

2 Department of Oncology, University of Torino Medical School, Candiolo, Italy

Competing Interests: No competing interests were disclosed.

\section{Erik H Danen}

Division of Toxicology, Leiden Academic Center for Drug Research, Leiden University, Leiden, The Netherlands

Competing Interests: No competing interests were disclosed.

The benefits of publishing with F1000Research:

- Your article is published within days, with no editorial bias

- You can publish traditional articles, null/negative results, case reports, data notes and more

- The peer review process is transparent and collaborative

- Your article is indexed in PubMed after passing peer review

- Dedicated customer support at every stage

For pre-submission enquiries, contact research@f1000.com 